\title{
SEALEX in-situ experiments-performance tests of repository seals: experimental observations and modelling
}

\author{
Nadia Mokni' ${ }^{a}$, Jean-Dominique Barnichon \\ Institute for Radiation Protection and Nuclear safety (IRSN), France.
}

\begin{abstract}
The paper describes observations and numerical analysis of SEALEX performance tests installed in Tournemire Underground Research Laboratory (URL). One of the objectives of the large scale in-situ tests is to investigate the impact of technological gaps on the long term performance of bentonite based seals. The swelling cores consist of precompacted blocks of a natural sodic Wyoming bentonite (MX80 type) mixed with quartz sand in a ratio of 70/30 (in dry mass) with different geometries (monolithic disks or four jointed disks). Several technological gaps exist within the in situ tests: Gaps between the blocks and annular gap with variable width between the bentonite-based core and the host rock. All the tests are extensively instrumented for monitoring the main Hydro-Mechanical (HM) variables. Comparison of the experimental results showed that the presence of technological gaps constituted new hydration sources (annular gaps) and flow paths (gaps between the blocks) that changed the saturation kinetics. A coupled HM formulation that incorporates the relevant processes involved in the problem under consideration has been adopted to analyse the effect of the annular technological gap on dry density homogenization of the bentonite based core as hydration progresses. Technological gaps were demonstrated to have an impact on dry density distribution.
\end{abstract}

\section{Introduction}

Highly compacted bentonites are often considered as sealing materials due to their low permeability, high radionuclide retardation capacity and high swelling ability (Pusch, 1979; Yong et al., 1986; Villar, 2008). Under geological disposal conditions bentonite will progressively hydrate and swell filling up the existing technological gaps. Various laboratory and in-situ experiments were conducted in the past to characterize the Hydro-Mechanical (HM) behaviour of these materials ([2], [3], [5], [7-12], [17], [18], [20]). However, little attention has been paid to the role and influence of technological gaps on the HM properties of the sealing materials during the saturation phase and especially on the degree of homogeneity of the bentonite based core at the end of the transient period. Still, the existence of technological gaps is generally neglected in numerical

\footnotetext{
a Corresponding author: nadia.mokni@irsn.fr
}

modelling and perfect contact is assumed between the different components of the sealing system.

In this context the SEALEX project was launched to specifically focus on long-term performance of sealing systems. This project relies on a series of in-situ experiments emplaced in IRSN's Underground Research Laboratory (URL) at Tournemire (South France). The SEALEX in-situ experiments aim to (i) quantify the impact of intra-core geometry (technological gaps) on the hydraulic properties of sealing systems, (ii) test the longterm hydraulic performance of sealing systems in normal conditions for different clay core compositions (pure bentonite or bentonite/sand mixtures) and conditionings (pre-compacted blocks or in-situ compacted), and (iii) investigate the concept of robustness by considering altered scenarios, such as an incidental decrease of the swelling pressure (for instance originating from the failure of the confining plugs). Accordingly, the experimental 
program was progressively implemented with six in-situ tests, changing one parameter at a time (core composition, conditioning, geometry...). The installation phase was undertaken from December 2010 to October 2013 and all tests are still currently ongoing. During the operational phases of the in-situ tests, the injected volume of water, swelling pressure at radial and axial directions, pore water pressure and relative humidity changes have been monitored at several positions within the seal.

The present paper presents the installation, analysis and interpretation of the experimental results of three ongoing SEALEX in-situ experiments (named PT-N1, PT-N2 and PT-A1). The analysis specifically focuses on the impact of technological gaps on the long-term performance of clay-based seals. A coupled HM formulation that incorporates the relevant processes involved in the problem under consideration has been adopted to analyse the effect of annular technological gap with non-uniform thickness, located between the bentonite based core and the host rock, on dry density homogenization of the bentonite seal as hydration progresses.

\section{Description of SEALEX in-situ tests}

\subsection{Test site location}

All the in-situ tests were conducted in IRSN's Tournemire URL (Figure.1), located in a Mesozoic sedimentary basin on the western edge of the French Causses (S France). The tests are situated in the $180 \mathrm{~m}$ thick shale formation (Toarcian-Domerian) that features typical anisotropic sheet textures induced by compaction processes. The mineral composition of the Tournemire shale is relatively homogeneous for the upper Toarcian section. It contains $39-51 \mathrm{wt} \%$ of phyllosilicates (smectite, illite, kaolinite, chlorite and mica), 24-36 wt $\%$ of quartz, $16-17 \mathrm{wt} \%$ of carbonates (bioclasts and diagenetic calcite are predominant and dolomite and siderite are in small proportions) and $4-8 \mathrm{wt} \%$ of $\mathrm{K}$-feldspaths. A small quantity of pyrite and organic matter are prevalent in the clay matrix. The shale is characterized by low porosity ( 8 $11 \mathrm{wt} \%$ ) with a water content of $3.5-4 \mathrm{wt} \%$ in the saturation state. Hydraulic permeability measurements give $10^{-21}-10^{-22} \mathrm{~m}^{2}$ in laboratory and $10^{-18}-10^{-21} \mathrm{~m}^{2}$ in-situ.

\subsection{Tested material}

The used bentonite is from Wyoming, USA, with high montmorillonite content $(80 \%)$. The cation exchange capacity (CEC) is $76 \mathrm{meq} / 100 \mathrm{~g}$ (Wang et al., 2012). It was provided by the Laviosa-MPC company, under the commercial name Gelclay WH2. The major exchangeable cation is $\mathrm{Na}+(83 \%)$. The liquid limit is $575 \%$, the plastic limit is $53 \%$ and the unit mass is $2.77 \mathrm{~g} / \mathrm{cm}^{3}$ ([21, [22]). The quartz sand used in the mixture comes from Eure and Loire (France) with a unit mass of $2.65 \mathrm{~g} / \mathrm{cm}^{3}$. It was sieved at $2 \mathrm{~mm}$ prior to being mixed with bentonite.

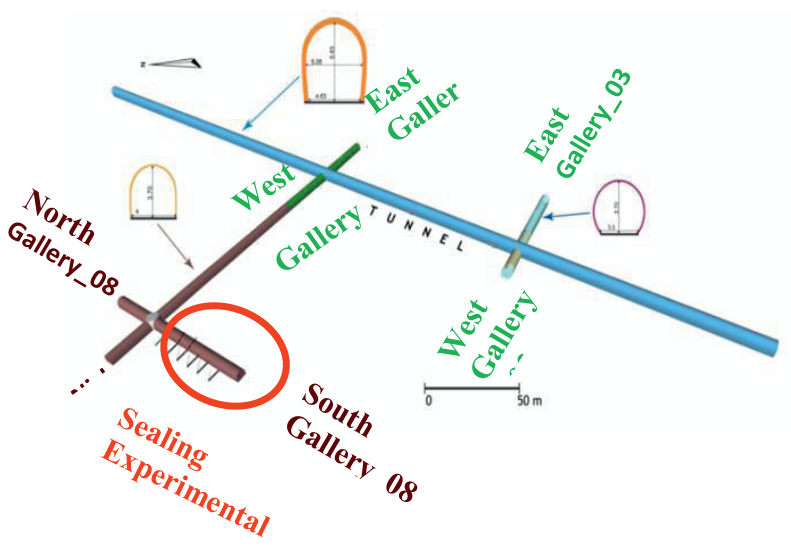

Figure. 1. Location of SEALEX in-situ experiments in Tournemire URL.

For the laboratory and in-situ tests, synthetic water used for hydration has the same chemical composition as the pore water of the Callovo-Oxfordian claystone from ANDRA URL in Meuse Haute la Marne (France) ([22]).

The bentonite blocks were obtained through uniaxial compaction of the mixture at a water content $\mathrm{w}=11 \%$ and dry density $?_{\mathrm{d}}=1.97 \mathrm{Mg} / \mathrm{m}^{3}$. This initial dry density was calculated taking into account the available radial technological gap. So that, the final dry density after filling the annular gap would be $1.67 \mathrm{Mg} / \mathrm{m}^{3}$.

\subsection{Testing geometry and operations}

Six SEALEX in-situ tests have been emplaced in horizontal boreholes (dip $0 \pm 2^{\circ}$ ), of $60 \mathrm{~cm}$ diameter and $5.4 \mathrm{~m}$ length, excavated into a $180 \mathrm{~m}$ thick shale formation (Toarcian-Domerian) at a height of $1.50 \mathrm{~m}$ above the URL gallery's floor (Figure.1). Each experiment consists of a bentonite-based core mechanically confined at both ends, which represents a generic seal mock-up, except for the artificial saturation system (Figure. 2).

SEALEX in-situ tests PT-N1, PT-N2 and PT-A1 have been designed to investigate the impact of intra-core 
geometry (technological gaps) on the performance of the clay-based seal. For these tests, the swelling core consists of pre-compacted blocks of a bentonite/sand mixture in a ratio of 70/30 (in dry mass) with different geometries. Two types of technological gaps exist within the experiments: gaps between the clay-based core and the rock (annular gap with non-uniform thickness) (Figure 2) and gaps within the clay core: between the block (PT-N1, PT-A1 and PT-N2) and within the blocks (PT-N2) (Figure.3). Dimensions of the clay core $(56 \mathrm{~cm}$ diameter, $120 \mathrm{~cm}$ in length) have been defined from scoping calculations of the re-saturation kinetics ([4]).

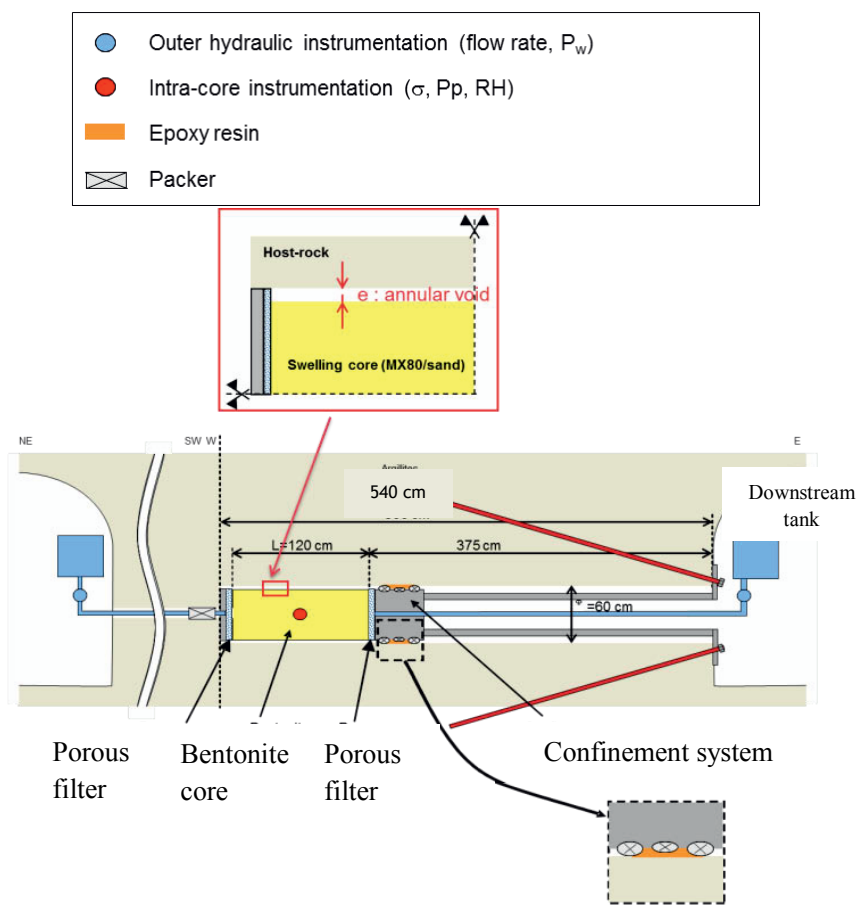

Figure. 2. Layout of SEALEX in-situ tests.

The clay seals in PT-N1 and PT-A1 are made up of 8 monolithic pre-compacted disks $(56 \mathrm{~cm}$ in diameter and $15 \mathrm{~cm}$ thick) (Figure. 3a). For PT-N2 the disks are divided in 4 sections with internal joints (Figure. $3 b$ ). The core is confined between two fixed stainless steel lids, namely upstream and downstream lid, which provide both hydraulic and mechanical closure (Figure. 2). The lids consist basically of a stainless steel circular plate and a cylindrical stainless steel tube welded all around its periphery. It has a series of three rubber inflatable cushions (O-ring) all around and passing for the hydration tubings. Once inflated with water, the O-rings close the gap between the plate and the surrounding rock.
A chamber filled up with an injected grout is left between the upstream lid and the flat end of the main borehole. The hydration surfaces at both sides of the lids are based on special geotextile mats fed with water distribution tubes. The reduction in thickness of the mats due to the swelling of the buffer is minimal up to $4 \mathrm{MPa}$.

The hydration system is equipped with a water distribution panel fed by a weighted stainless steel water tank connected with inflow lines to both hydration surfaces (downstream and upstream). The confining system consists of a support tube inserted into the cylindrical tube of the downstream lid up to rest against the circular plate and of a closure plate $(1400 \mathrm{~mm}$ in diameter) placed at the outer face of the borehole and secured by four bolts anchored to the rock. For test PTA1, a second tube is added. The coupling acts as a piston and allows the movement of the plate (in contact with the bentonite core) when the confinement is released.

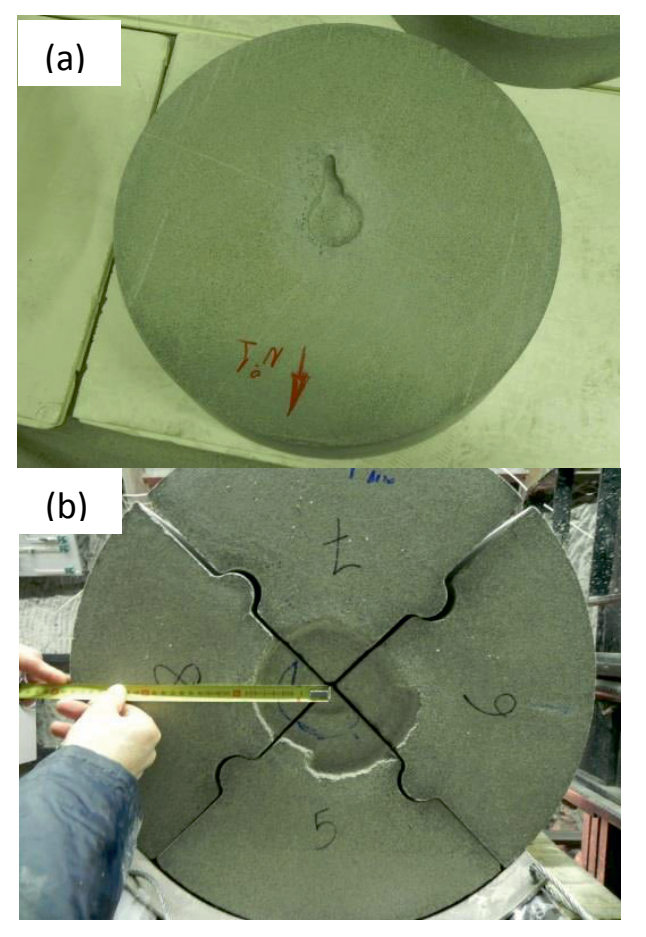

Figure. 3 (a) Bentonite monolithic disks used in tests PT-N1 and PT-A1. (b) Jointed quarters of disks used in PT-N2.

In order to avoid potential flow paths along cables and sensors, and thereby, to limit as much as possible the disturbance of the clay core wireless sensors have been used. Three types of sensors have been installed within the compacted blocks: 5 total pressure cells, 8 pore pressure sensors and 8 relative humidity sensors

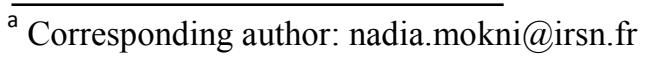


(Figure.4). Three total pressure sensors have been installed on the surface of the core at $60 \mathrm{~cm}$ from the downstream saturation face to measure the radial swelling pressure. Two total pressure sensors have been installed at 0 and $120 \mathrm{~cm}$ from the downstream saturation face to measure axial swelling pressure. The blocks have been mechanized to house the sensors and the wireless transmitter. The remaining gaps have been then filled up with MX80 bentonite powder to minimize preferential flow paths.

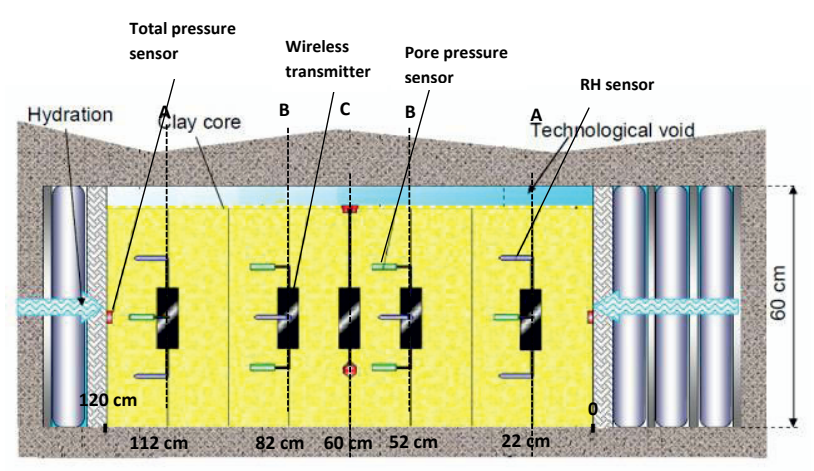

Figure. 4. Distribution of RH, pore pressure, and swelling pressure sensors in the seal.

Hydration has been performed following 2 phases: First, a back pressure of 0.2 MPa was applied in the tank, which allowed filling the gap between the rock and the device in 2 hours. Second, the back pressure was removed, and the upper level of the water in the tank was constantly maintained at $1 \mathrm{~m}$ above the axis of the borehole (i.e. $1 \mathrm{~m}$ water head).

\section{Results and comparison}

\subsection{Impact of technological gaps on saturation kinetics}

Eight relative humidity sensors were installed in each bentonite core at 22, 52, 82 and $112 \mathrm{~cm}$ from the downstream hydration face (Figure. 4). Figure 5 compares RH evolution over time measured at RH-52-1 and RH-522 in PT-N1, PT-N2 and PT-A1. The curves show a monotonic increase of $\mathrm{RH}$ corresponding to the progress of saturation caused by water drawn from the hydration downstream and upstream ends and the annular technological gap. Independently of the distance to the wetting sources, a faster increase of RH is observed in PT-N2 which is probably the consequence of water initially infiltrating the intra and inter-disks technological gaps.

\subsection{Impact of technological gaps on swelling pressure}

During hydration radial swelling pressures were monitored using three total pressure cells installed on the surface of the bentonite based core at $60 \mathrm{~cm}$ from the downstream saturation face. Figure 6 compares the evolution of the radial swelling pressure at each sensor for PT-N1 and PT-N2. No comparison could be made with PT-A1 due to the lack of data (malfunctioning of the data acquisition system (DAS)). For PT-N1, the swelling pressures increased over time at different rates, depending on the sensor position. Higher swelling rates are observed at the sensor located at bottom right hand side (sensor S03). However, the swelling pressure level off at 400 days and reaches $1.8 \mathrm{MPa}$ after 600 days. Slower swelling rates are observed at S02 and S01, but the swelling pressures increase at constant rates until the interruption of the data acquisition at 800 days (due to a problem in the DAS unit). The lowest swelling pressure is measured at the top of the core (sensor S02), where the annular gap between the bentonite and the rock was wider and therefore the confinement was lower.

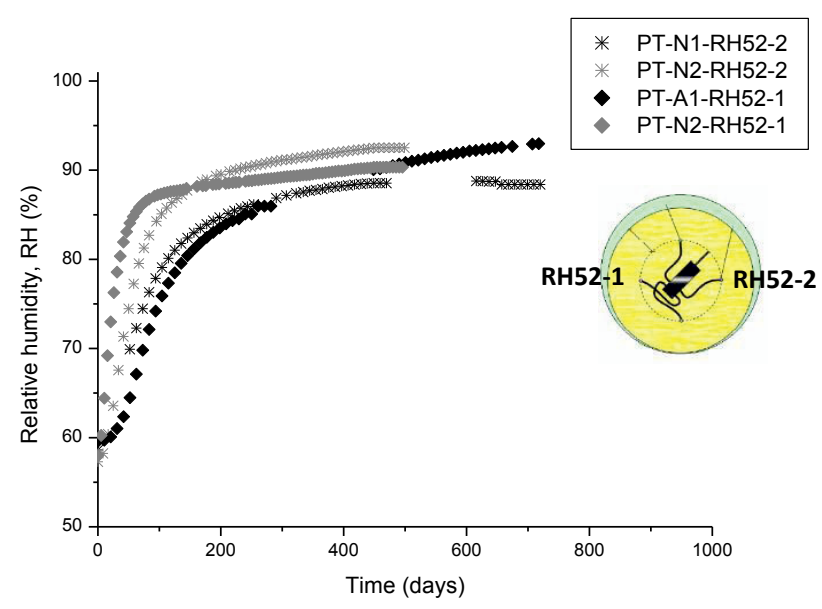

Figure. 5. Comparison of RH evolution in PT-N2, PT-N1 and PT-A1 measured at different distance from the hydrations sources.

In test PT-N2, a significantly lower and rapid stabilization (after 200 days) of the swelling pressure is observed. At S02 located on the top of the clay core, where the annular technological gap is the wider, comparable swelling rates are measured in PT-N1 and PT- 
N2 at least during the first 200 days. After this time period, the swelling pressure levels off in PT-N2. The observed lower swelling rates might be attributed to the initial self-sealing of the additional technological gaps existing within and between the clay jointed disks in this in-situ test.

The significant difference between the radial swelling pressures, observed in PT-N1, suggests a heterogeneous structural distribution of the bentonite/sand mixture within the blocks. Saba et al. (2014a, b) used microfocus X-ray

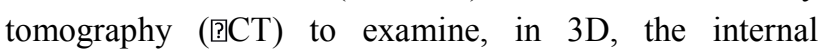
microstructure of a bentonite/sand (70/30) sample (38 mm diameter, $10 \mathrm{~mm}$ height), as compacted at $\mathrm{d}=1.8$ $\mathrm{Mg} / \mathrm{m}^{3}$ and after four months of hydration, in constant volume conditions. Continuity between the sand grains with interconnected inter-grain large pores has been detected at different locations within bentonite/sand mixture. Furthermore, a concentration of larger macropores between either sand grains or bentonite grains has been observed around the sample. Saba et al. (2014b) concluded that this heterogeneity has an impact on the swelling pressure measured on the radial and axial directions.

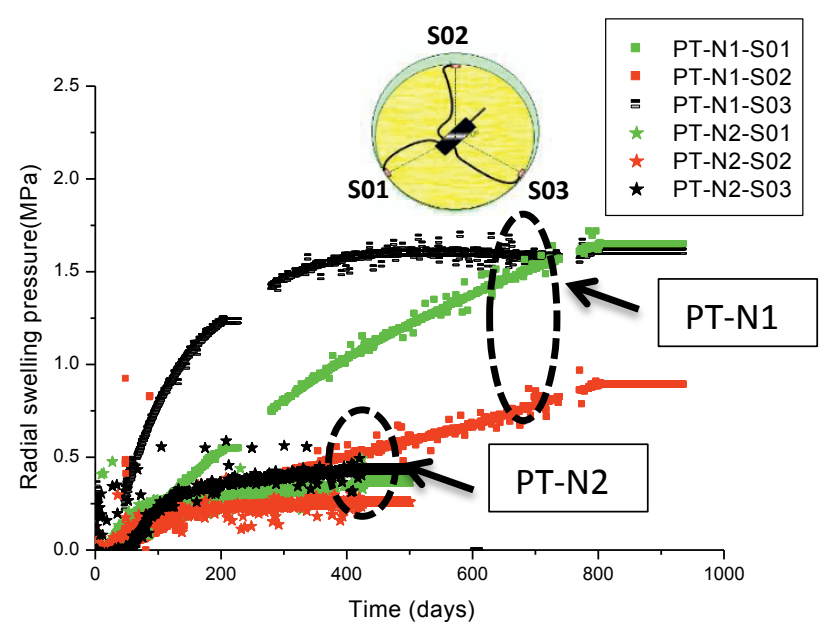

Figure. 6. Evolution of radial swelling pressure in tests PT-N2 and PT-N1 measured in 3 sensors located at $60 \mathrm{~cm}$ from the downstream hydration face.

\subsection{Impact of technological gaps on dry density distribution}

In order to investigate the effect of closure of technological gaps on bentonite dry density homogenisation, a hydro-mechanical coupled analysis of SEALEX in-situ test PT-N1 has been performed. The numerical analysis has been carried out using the finite element code CODE_BRIGHT ([6]).

A key feature in the simulation lies in the appropriate modeling of the bentonite-sand mixture hydro-mechanical behavior. A detailed description of the HM constitutive laws used to describe the behaviour of the bentonite based seal could be found in [13]. To represent the mechanical behaviour of the material, the well-known mechanical elasto-plastic Barcelona Basic Model, (BBM) ([1]) has been used.

The model parameters have been first calibrated against conventional laboratory tests ([13]). Two sets of laboratory experiments have been modelled: the first involves characterising the hydro-mechanical behaviour of the 70/30 MX80 bentonite/sand mixture (infiltration tests, swelling/ compression tests under controlled suction conditions); the second is a $1 / 10$ th scale mock-up of the SEALEX experiment ([13]).

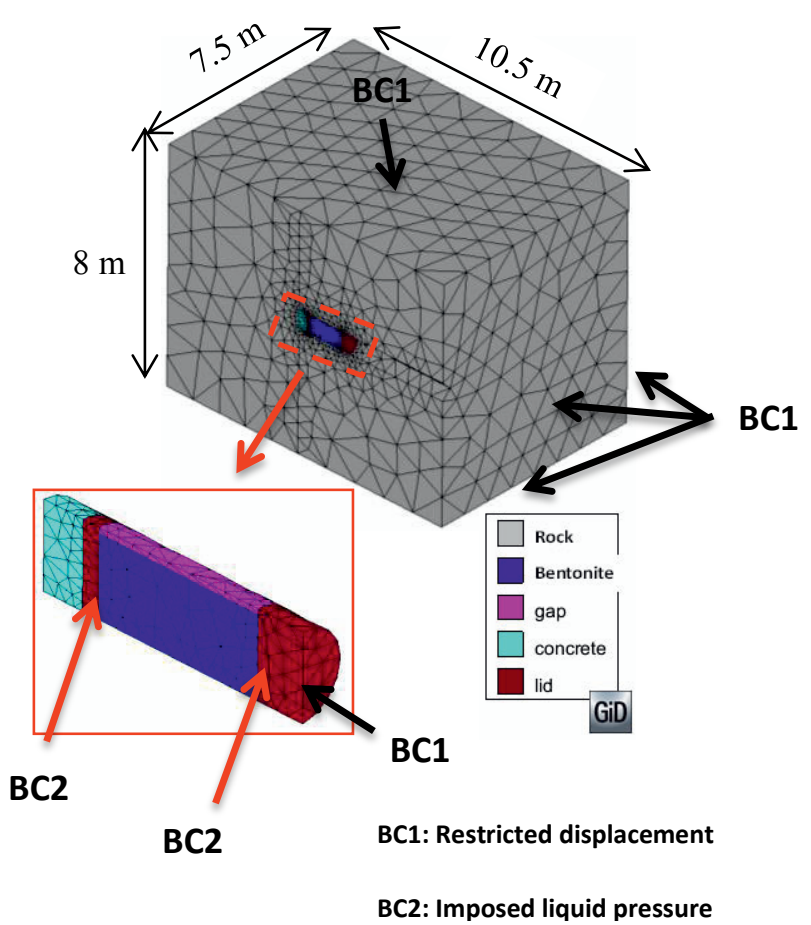

Figure. 7. Model geometry, mesh and boundary conditions.

The HM coupled analysis has been performed using a 3-D finite element model that includes the hydration systems (downstream and upstream lids), the concrete block between the host rock and upstream lid, the bentonite based core, the surrounding host-rock and the annular gap with variable thickness that exists between the bentonite based core and the host rock. Only one half of the problem is analysed because of symmetry (Figure.

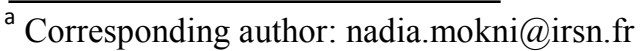


7). A fundamental issue in modeling SEALEX in-situ test lies in properly representing the initially air-filled gap with variable thickness ( 0 at the bottom of the bentonite based core and $4 \mathrm{~cm}$ at the top). As a first approach, this gap is modelled as a material with high porosity and high permeability. A dependence of the retention curve and permeability on porosity has also been taken into account. The mechanical response of the gap is achieved using a nonlinear elastic model with stiffness values evolving with porosity defined as ([13]),

$$
\text { if } \begin{array}{lr}
\phi>\phi_{0}, & E=\frac{E_{0}}{\phi-\phi_{0}} \\
\text { else } & E=E_{\max }
\end{array}
$$

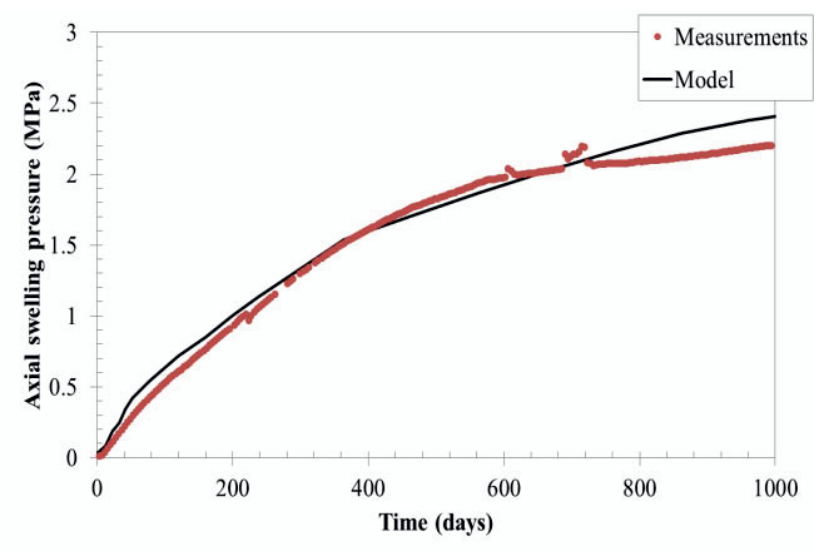

Figure. 8. Evolution of axial swelling pressure at a sensor placed at the downstream saturation face in test PT-N1.

Comparing modelling results with field observations, the model predict reasonably well the evolution of axial swelling pressure (Figure.8), and relative humidity (Figure.9) at different points of the clay core. Changes in dry density for three different times (140, 500 and 1000 Days) are displayed in Figure. 10.

A heterogeneous distribution of dry density is observed. For a given hydration time, low densities prevail at the outer boundary due to the swelling of the bentonite to fill up the non-uniform thickness annular gap, but they increases progressively towards the centre of the core. As hydration progresses, this decrease in density prevails wider into the interior core.

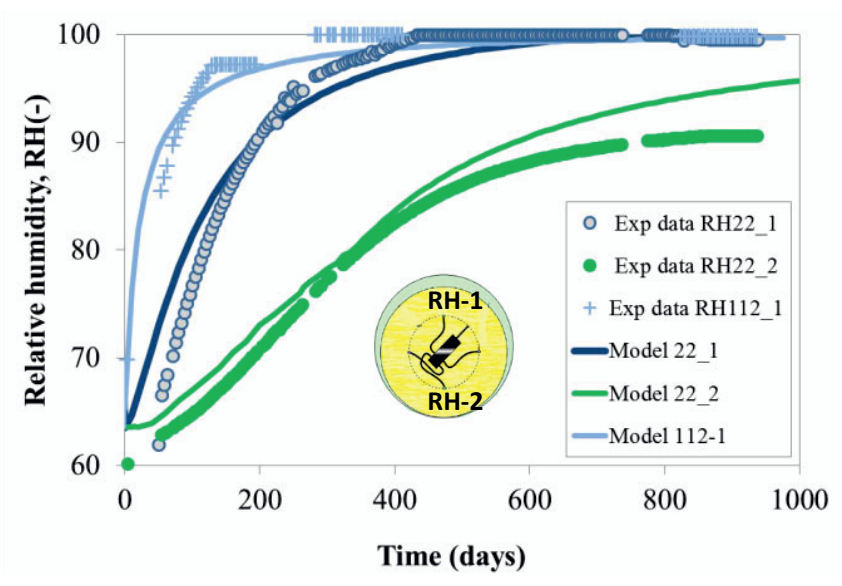

Figure. 9. Evolution of relative humidity at different distance from hydrations sources for SEALEX performance test PT-N1. Experimental and Modelling results.

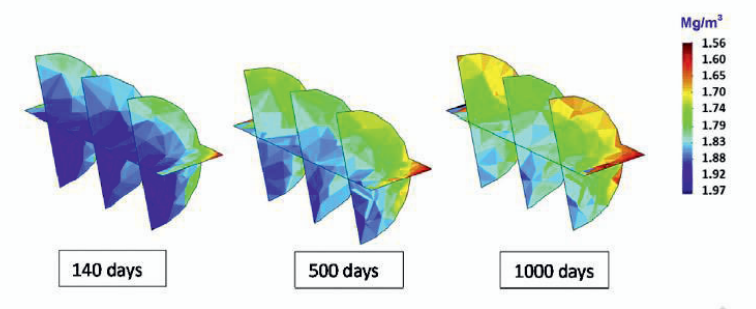

Figure. 10. Contour maps of dry density from Time $=140$ to 1000 days.

\section{Concluding remarks}

Technological gaps left between the pre-compacted plug and the host rock may impact the long term performance of the sealing system. For PT-N1 and PT-A1 which have similar clay core geometries, higher saturation rates have been observed at RH sensors located close to the annular technological gap. The latter constituted a new hydration source that allowed together with the installed hydration system the simultaneous radial and axial hydrations of the bentonite core. The presence of additional technological gaps within the clay jointed disks in PT-N2 did have a great impact on the saturations kinetics since it constituted additional infiltration paths. The effect of technological gaps was also evidenced when comparing the swelling pressure kinetics: the evolutions rates of radial swelling pressure were significantly lower in PT-N2. This difference is attributed to the initial self-sealing of the technological gaps existing within the clay disks in PTN2. Technological gap was demonstrated to have an impact on dry density distribution. Model results demonstrated the non-uniform closure of the gap which induces a heterogeneous distribution of dry density 


\section{Acknowledgments}

The authors would like to thank AITEMIN (Spain) and ENPC-CERMES (France) our partners in this project.

\section{References}

1. Alonso, E. E., Gens, A., and Josa, A. Géotechnique 40(3), 405-430. (1990)

2. Börgesson, L., Chijimatsu M., Fujita, T., Nguyen, T.S., Rutqvist, J., Jing, L.,. International Journal of Rock Mechanics and Mining Sciences 38, 95-104. (2001)

3. Barnichon, J.D., and Deleruyelle, F. EUROSAFE. (2009)

4. Barnichon J.D., Dick P. and Bauer C.,. Qian \& Zhou (eds) Taylor \& Francis Group, London. ISBN 978-0415-80444-8, pages 1391-1394. (2012)

5. Delage P., Howat M. D. and Cui Y. J.,. Engineering Geology 50, 31-48. (1998)

6. DIT-UPC, 2000. CODE-BRIGHT. User-s guide. CIMNE, Barcelona.

7. Gens, A., Vallejan, B., Sánchez, M., Imbert, C., Villar, M.V, and Van Geet, M., 2011. Geotechnique 61(5):367-386, (2011).

8. Imbert C. and Villar M.V. Applied Clay Science, 32(34):197-209. (2006)

9. Lloret, A., and Villar, M.V., Sanchez, M., Gens, A.. Geotechnique 53 (1), 27-40.(2003)

10. Lloret, A., and Villar, M.V., Sanchez, M., Gens, A.,. Physics and Chemistry of the Earth 32 701-715. (2007)

11. Mayor, J.C., García-Siñeriz, J.L., Alonso, E.E., Alheid, H-J., Blümbling, P.. Final report Publicación técnica ENRESA 02/05. Madrid, 101 pp.(2005)

12. Martino, J.B., Dixon, D.A., Vignal, B., Fujita, T. WM'06 Conference, Febururay 26-March 2, 2006, Tucson, AZ.

13. Mokni, N., Barnichon, J.D. Engineering Geology 205: 81-92.(2016)

14. Pusch, R., 1979. Nuclear technology 45 (2), 153-157 United States.(1979)

15. Saba, S., Delage, P., Lenoir, N., Cui, Y.J., Tang, A.M. and Barnichon, J.D. Engineering Geology 168: 141148. (2014a)

16. Saba, S., Barnichon, J.D, Cui, Y.J., Tang, A.M. and Delage, P.,. Journal of Rock Mechanics and Geotechnical Engineering 6: 126-132. (2014b)

17. Volckaert, G., Dereeper, B., Put, M., Ortiz, L., Gens, A., Vaunat, J., Villar, M.V., Martín, P.L., Imbert, C., Lassabatère, T., Mouche, E., Cany,F.. Reseal projectPhase I. EUR 19612. Commission of the European Communities, Luxembourg. 273.pp.(2000)

18. Van Geet, M., Bastiaens, W., Volckaert, G., Weetjens, E., Sillen, X., Maes, N., Imbert, C., Billaud, P., Touzé, G., Fillippi, M., Plas, F., Villar, M.V., GarcíaGutiérrez, M., Mingarro, M., GensA., Vallejan, B.,.
RESEAL II. Final report.: EUR 24261, Nuclear Science and Technology, European Commission, Luxembourg, 288 pp.(2009)

19. Villar M.V.. Publicación Técnica ENRESA 01/2002, Madrid, 258 pp.(2008)

20. Villar M.V., Gómez-Espina, R., Campos, R., Barrios, I., Gutiérrez-Nebot, L.. Unsaturated soils: Research and Applications, vol. 1. Springer, Berlin, pp. 137144.(2012)

21. Wang Q., Tang A.M., Cui Y.J., Delage P. and Gatmiri B.,. Engineering Geology 124: 59-66, doi : 10.1016/j.engeo.2011.10.003.(2012)

22. Wang, Q., Tang, A. M., Cui, Y.J., Barnichon J.D. \& Ye W.M.. Engineering Geology, Vol. 162, 7987.(2013a)

23. Yong, R.N., Boonsinsuk P. and Wong G., 1986. Canadian Geotechnical Journal, 23(2):216228.(1986)

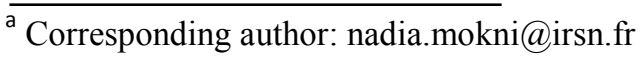

